\title{
"NÃO SENDO OS AFRICANOS LIBERTOS NASCIDOS NO BRASIL...”: A LEGISLAÇÃO ANTIAFRICANA NA BAHIA DO SÉCULO XIX (1824-1835)
}

\author{
FÁBIO RAMOS BARBOSA FILHO ${ }^{1}$ \\ (IEL/UNICAMP)
}

\begin{abstract}
RESUMO: Busca-se neste trabalho, a partir da leitura de um conjunto heterogêneo de documentos, compreender as relações (de sentido) entre o poder político baiano e os africanos escravos e libertos na Bahia do século XIX. A leitura proposta busca colocar em relevo o próprio da Análise de Discurso diante de outros gestos de leitura de documentos, trabalhando a língua em sua materialidade, ou seja, a partir do conjunto diferencial de determinações que constituem a sua espessura histórica. O recorte temporal que nos interessa é, sobretudo, o período entre 1824 (ano de outorga da primeira Constituição brasileira) e 1835, quando a "revolta dos Malês" se institui como argumento categórico à composição de um corpo legal ostensivo e intolerante com a presença africana na Província da Bahia e, de modo geral, no resto do Brasil. Nessa conjuntura, os sentidos de "africano" funcionam fora do puro campo da evidência toponímica, dando visibilidade a uma rede de discursividades que se atravessam e determinam os sentidos de "nação", "Império", "cidadão" e "brasileiro". Assim, os sentidos de "africano" entram no campo do litígio, desorganizando/reorganizando o discurso jurídico dos oitocentos e dando, ao mesmo tempo, visibilidade às contradições e limites políticos da formação social baiana diante de uma alteridade inegociável e insuportável face ao projeto nacional e modernizador no Brasil.
\end{abstract}

Palavras-chave: discurso; arquivo; história.

RÉSUMÉ: On cherche dans ce travail, à partir de la lecture d'un ensemble hétérogène de documents, à comprendre les rapports (de sens) entre le pouvoir politique bahianais et les africains (esclaves et libres) dans la Bahia du XIXème siècle. On propose, donc, une lecture qui souligne la singularité de l'Analyse du Discours par rapport à d'autres pratiques de lecture de documents, en travaillant la langue dans sa matérialité, c'est-à-dire à partir de l'ensemble différentiel de déterminations qui constitue son épaisseur historique. Ce qui nous intéresse ici c'est surtout la période entre 1824 (année de publication de la première Constitution brésilienne) et 1835, lorsque la "révolte des Malês » est devenue l'argument catégorique à la composition d'un ensemble de lois très intolérant à la présence africaine dans la «Província da Bahia » et, d’une façon générale, au Brésil. Dans cette conjoncture, les sens d' " africain » fonctionnent en dehors de l'évidence toponymique et nous permet de voir un réseau de discursivités que se traversent et déterminent les sens de « nation », «Empire », « citoyen » et « brésilien ». Ainsi, les sens d' « africain » entrent dans le champ du litige, en désorganisant/réorganisant le discours juridique du XIXème siècle et, en même temps, en donnant visibilité aux contradictions et limites politiques de la formation sociale bahianaise devant une altérité innégociable et insupportable devant le projet national et modernisateur au Brésil.

Mots-clés: discours; archive; histoire.

${ }^{1}$ Pós-doutorando em Linguística (IEL/UNICAMP), sob a supervisão do Prof. Dr. Lauro José Siqueira Baldini. E-mail: fabioramosbf@gmail.com 


\section{INTRODUÇÃO}

"Presentemente tudo mais está tranquillo, e teremos tempo de, por medidas Legislativas Provinciaes, providenciar de maneira que não seja segunda vez preciso lutar com tal gente, e muito menos com africanos forros, que quasi todos, no gozo da liberdade, trazem o ferrete da escravidão, e não utilizam nada o Paiz com sua estadia"

Francisco Gonçalves Martins, chefe de polícia da Bahia no ano de 1835, em carta ao presidente da Província

No dia 22 de janeiro de 1808 a família real chega a Salvador. Sem demora, já no dia 28, é emitida a primeira versão da Carta Régia que ganhou, posteriormente, o nome de Decreto da abertura dos portos do Brasil. Esse decreto permitiu a solução para um problema que perturbava os comerciantes da cidade da Bahia: a ausência de navios no porto devido às questões diplomáticas e militares envolvendo Portugal na conturbada conjuntura europeia. Amplamente liberal, a medida protegia produtos tradicionalmente produzidos por Portugal (como azeites e vinhos), mas representava uma guinada na dinâmica comercial baiana, que viu a possibilidade de crescimento do processo de exportações pela inclusão do Brasil no já movimentado circuito econômico do Atlântico.

Do ponto de vista político e administrativo, a chegada do governo português no Brasil representou uma verdadeira revolução institucional com a instalação de um aparato burocrático até então inédito e um súbito (e vultoso) aumento nos impostos, que serviam a manutenção da Corte no Rio de Janeiro. Vale mencionar que o governo era "centralizado, altamente burocrático, vigilante e repressivo para com o menor gesto ou indício de contestação a impostos, taxas e proibições" (TAVARES, 2006, p. 214).

Já com feição urbana, Salvador possuía à época dez freguesias: Ao lado da Sé, primeira freguesia da cidade, fundada em 1552, ou seja, três anos após a chegada de Tomé de Souza, havia as freguesias da Vitória, Conceição da Praia, Santo Antônio além do Carmo, São Pedro Velho, Santana, Rua do Passo, Nossa Senhora de Brotas, Pilar e Penha. Freguesia, como explica Anna Amélia Nascimento, significa "o conjunto de paroquianos, povoação sob o ponto de vista eclesiástico" (NASCIMENTO, 2007, p. 44). Em suma, uma divisão políticoadministrativa determinada pelo religioso significava a distribuição dos espaços na cidade.

A despeito da vergonha das elites face ao "passado arcaico", subsistem traços, resquícios visíveis da produção colonial em uma cidade que ansiava a modernização a qualquer preço. E talvez o mais agudo e contraditório dos traços coloniais seja a articulação entre e trabalho escravo e economia exportadora. Essa relação institui marcas, efeitos urban(ístic)os e sociais singulares sob um modelo econômico que produz uma cidade "que não segue as formas do modelo clássico de urbanização fundado na análise do processo urbano nas áreas centrais do sistema capitalista" (COSTA, 2010b, p. 235). Salvador, assim como a maioria das cidades brasileiras do século XIX, é, pois, o resultado de um "modelo de urbanização característico de áreas de economia colonial e periférica às quais não se ajusta o modelo clássico" (ibidem, p. 236). Nesse contexto, o seu porto possuía uma função primordial e 
representava o núcleo do dinamismo comercial da cidade, razão pela qual muitos escravos e libertos migraram do Recôncavo após a crise do açúcar para tentar a sorte nas ruas da cidade. Era de lá que saía e chegava a maior parte de um grande fluxo de mercadorias do exterior, de fora da Província e do Recôncavo.

Em termos demográficos, a soma de Salvador com o Recôncavo totalizava uma população de 110.000 habitantes em 1798 e 156.000 em 1808 . Entre 1775 e 1807 Salvador cresceu 31\%. A hipótese utilizada aqui, a título de ilustração, será a proposta por João José Reis, que estipula uma população de 65.000 pessoas em Salvador em 1835. Reis afirma ainda que "a população africana e afro-baiana, incluindo escravos e livres, aumentou 39 por cento, e sua proporção em relação ao total de habitantes pulou de 64 para 72 por cento" (REIS, 1986, p. 15). Os pretos - como eram chamados os negros africanos - compunham um setor basicamente escravo (79\%) em um cenário onde o trabalho na cidade e do campo possuía quase toda a escravidão movida pela mão de obra estrangeira. Mesmo assim "todas as estimativas sobre Salvador reportam sempre um número de escravos inferior ao de livres e libertos" (ibidem, p. 16), embora essa diferença não seja tão larga. Em 1835, estima-se que 42\% da população era composta por escravos e o restante, 58\%, de libertos e livres. Os negros contabilizavam $71 \%$ da população e os brancos eram, nos temos de Reis, "minoria racial".

Outros setores que cresciam paralelamente ao binômio senhor/escravo desempenharam um papel fundamental no tecido social baiano oitocentista e na formação de um cenário singular no trabalho de rua, como os pobres livres. Estes eram, ao lado dos escravos, a maioria da população desde a segunda metade do século XVIII sendo esse quadro intimamente relacionado a uma imensa concentração de renda onde $66 \%$ da riqueza pertencia a $10 \%$. A respeito da pobreza, os arquivos relatam a crescente insatisfação por meio de "relatórios de juízes de paz e outras autoridades que se queixavam diariamente do número crescente de mendigos e desocupados que vagavam por suas freguesias, pessoas que já haviam ultrapassado o limiar da pobreza para serem absolutamente pobres" (ibidem, pp. 21-22). Esse cenário revela uma crescente forma de pobreza urbana que se configura no século XIX.

A questão escrava na Bahia era peculiar. Não havia uma rigidez pragmática que fizesse a escravidão ser um modelo próximo ao de castas, mesmo sendo uma sociedade onde "milhares de seus habitantes permaneciam propriedade legal de outros homens e mulheres, e o racismo e a intolerância étnico-cultural desempenhavam um papel importante na definição de quem devia obedecer e quem dar ordens" (ibidem, p. 21). Essa relação estava ligada, sobretudo, ao ideal de uma nação que começava a vislumbrar a sua forma a partir da continuidade das práticas sociais europeias. Nesse caso, os africanos "podiam desfrutar algum sucesso no mundo material, mas ao preço de alianças sociais que geralmente significavam o sacrifício de boa parte de sua independência, dignidade e identidade" (ibidem, p. 21). 
O historiador baiano Luís Henrique Dias Tavares assevera que o africano era fundamental em todas as atividades do campo e da cidade, sendo uma espécie de meio de produção primordial na economia colonial. Ele diz que "a importação de escravos africanos para a Bahia começou em seguida ao estabelecimento dos primeiros engenhos de açúcar" e enfatiza que "não muito antes de 1549 e nem muito depois de 1550" (TAVARES, 2006, p. 52), o que significa que a chegada do escravo corresponde à demanda da produção agrícola exportadora. Tavares continua afirmando que

a economia da província da Bahia permaneceu baseada no trabalho escravo ao longo de 88 anos do século XIX. Era uma economia agrária e dependente da economia internacional dominante, o capitalismo mercantil migrando para o capitalismo industrial. Comparada à do período colonial, registra-se que diversificou a sua pauta de exportação e ampliou as suas atividades mercantis (ibidem, p. 282)

Entre a chegada incipiente, o fluxo massivo e a proibição, o poder público e os senhores de escravos sempre tiveram que lidar, cada um à sua maneira, com a ameaça da insurreição e insubordinação escrava e negra. Desde o marcante episódio da insurreição dos Malês, em janeiro de 1835, o poder político endureceu a sua relação com os africanos e, de modo mais amplo, com o corpo negro. $\mathrm{O}$ pavor do "haitianismo", (a revolta negra que subverteu as relações de poder no país caribenho), fez com o que o medo branco ${ }^{2}$ se institucionalizasse e ganhasse forma jurídica e administrativa. Nessa época foram produzidos, portanto, dispositivos que previam uma completa arbitrariedade policial e legislativa contra os africanos e, de modo mais geral, contra o corpo negro.

Sobre essa questão cabe uma precisão conceitual: quando trato da questão do controle (e da revolta) a partir do viés do corpo (e não do "trabalhador" ou do "indivíduo") é para acentuar a radicalidade das práticas de Estado e do poder econômico que se desenvolvem não apenas sobre o conceito jurídico de "pessoa", mas sobre a materialidade corporal desses sujeitos: sobre a carne, sobre a pele. Na conjuntura dos oitocentos, o corpo negro é base de processos de significação. É marcado e significado materialmente, pela inscrição, pela ranhura na carne, ou por metáforas e metonímias que jogam com um corpo fragmentado. Esses corpos, no entanto, não são indiferentes a todas essas determinações: são corpos que resistem e, sobretudo, simbolizam, significam essa resistência. Corpos que falam, gritam, debocham, ironizam, se organizam politicamente, intrigando o arquivo e instigando o rumor. Corpos táticos, políticos, simbólicos.

${ }^{2}$ Azevedo, 1987. 


\section{OS RUDIMENTOS DA LEGISLAÇÃO ANTIAFRICANA}

O Brasil possui desde 1824 uma Constituição. Em relação ao corpo negro (e, sobretudo, o corpo negro escravizado) ela era clara: silêncio. A Constituição de 1824 "ignorou os escravos" (COSTA, 2010a, p. 16). Não existe, no documento, nenhuma menção ao escravismo, modo de produção então dominante no país. A Constituição decreta e faz saber aos Subditos um acontecimento: a nova ordem administrativa e política do Brasil. É nessa ocasião que o Imperador vai fazer saber aos seus "subditos" que o império "é a associação Política de todos os Cidadãos Brazileiros" ${ }^{\prime \prime}$ e os escravos e africanos, como não eram nem cidadãos nem estrangeiros, só tinham lugar nas arbitrariedades das decisões judiciárias. É importante assinalar que no tocante às cidades, a Constituição de 1824 cria as Câmaras Municipais, responsáveis pelo "governo economico, e municipal das mesmas Cidades, e Villas". ${ }^{4}$ As Posturas, dispositivos jurídicos que ordenavam a vida municipal, eram de responsabilidade dessa recém-criada instituição. $\mathrm{O}$ território da Bahia estava, então, circunscrito à responsabilidade do Governo Provincial, criado pelos artigos 165 e 166, e do poder municipal, representado pela Câmara.

Em 1830, com a criação do Código Criminal, a relação entre os escravos e o poder político se reconfigura no corpo das leis. O Código tipifica, no título IV, cinco crimes "contra a segurança interna do Imperio, e publica tranquilidade" 5 e, dentre eles, o crime de insurreição. Segundo o documento, configura insurreição "vinte ou mais escravos para haverem a liberdade por meio de força". ${ }^{6}$ Nessa mesma época, no âmbito municipal, duas Posturas em Salvador chamam atenção: a de 25 de fevereiro de 1831 que estabelece "multa de 8000 réis ou quatro dias de prisão ao dono de tendas, botequins, tavernas e mais casas de mercado público que consentisse algazarras, jogos não permitidos por lei e demora de escravos"7 e a de 25 de fevereiro que proibia "batuques, danças e ajuntamentos de escravos em qualquer hora e lugar, sob pena de oito dias de prisão". ${ }^{8}$

Ainda mais incisivo, o Decreto de 14 de dezembro de 1830 "estabelece as medidas policiaes, que na Provincia da Bahia se devem tomar com relação aos escravos, e aos pretos forros africanos". $\mathrm{O}$ artigo $3^{\circ}$ desta lei é fundamental para que se compreenda a que ponto estavam as relações de hostilidade. Diferentemente das leis medidas em relação, o artigo diz o seguinte:

\footnotetext{
3 Constituição Política do Império do Brazil (CPIB), p. 1.

${ }^{4}$ CPIB, p. 14.

5 Código Criminal do Império do Brazil (CCIB), pp. 12-13.

${ }^{6}$ CCIB, p. 13.

${ }^{7}$ Repertório de fontes sobre a escravidão existentes no Arquivo Municipal (RFE), p. 48.

8 Idem.
} 
Art. $3^{\circ}$ Nenhum preto, ou preta, forros africanos, poderá sahir da cidade, villas, povoações, ou fazenda, e prédio, em que fôr domiciliario, á titulo de negocio, ou por outro qualquer motivo, sem passaporte, que deverá obter do Juiz criminal, ou de Paz lugar, a arbitrio das partes, os quaes sómente lh'o concederão, precedento exame da regularidade da sua conducta por meio de tres testemunhas, que a abonem (caso não seja conhecida e abonada pelo mesmo Juiz) e em taes passaportes não sómente se indicará o nome do indivíduo, que o requereu, seus mais disctintos signaes, e o lugar para onde se encaminha (como é de costume) mas tambem se designara o tempo, por que devam durar os ditos passaportes, po quanto ha toda a preseumpção, e suspeita de que taes pretos são os incitadores, e provocadores de tumultos, e comoções, á que tem se abalançado os que existem na escravidão.

Diante dessa profusão de medidas, os africanos libertos e escravos resistiram. Veremos, a partir de agora, de que modo essas relações se textualizaram no arquivo.

\section{O CONTROLE DO CORPO NEGRO PÓS-1835}

Mesmo que o arquivo registre o lamento branco e a indignação daqueles que possuem o aparato documental e as políticas de inventário para inscrever e registrar tanto as suas glórias quanto as suas perdas, nenhum setor da formação social baiana oitocentista sofreu tanto quanto os africanos libertos, sobretudo após o levante de janeiro de 1835 que a historiografia consagrou como "revolta dos Malês". Para além de todos os prejuízos implicados em não ter "nem direito de cidadão, nem privilégio de estrangeiro", 9 para além do cativeiro e da liberdade transitiva, ${ }^{10}$ uma liberdade segunda, dependente, distinta da liberdade intrínseca do branco (e, principalmente, determinada por esta) a repressão, a violência, a arbitrariedade policial e judiciária atingiram níveis que beiravam, até para os padrões da época, o absurdo. Um sentimento de retaliação generalizada acompanhou, passo a passo, o medo e o desejo de vingança da população branca e mestiça. ${ }^{11}$

As autoridades políticas, por sua vez, contemporizavam, adotando um estilo que simulava a diplomacia. O presidente da Província, em carta ao ministro da justiça do Império, disse que "não sendo os africanos libertos nascidos no Brasil, e possuindo uma linguagem, costumes e até religião diferente dos brasileiros, e pelo último acontecimento, declarando-se tão inimigos da nossa existência política, eles não podem jamais ser considerados cidadãos brasileiros para gozar das garantias afiançadas pela Constituição". ${ }^{12}$ Não "linguagem, costumes e até religião diferente dos brasileiros", mas "uma linguagem, costumes e até religião diferente dos brasileiros". O artigo indefinido, aqui, define, circunscreve e impõe medida à tensão em torno de uma alteridade necessária ou negociável e uma alteridade rejeitada ou proibida

\footnotetext{
${ }^{9}$ Francisco Gonçalves Martins, chefe de polícia. In: Reis, 2003, p. 421.

10 Viana, 2008.

11 Os mestiços, maioria absoluta do aparato repressivo, alimentavam um profundo antiafricanismo. A esse respeito, ver Reis, 2003.

${ }^{12}$ In: Brito, 2010.
} 
que definiria, no decurso do século, as relações de hostilidade e hospitalidade adotadas pelo Estado brasileiro. De modo mais amplo, definiria o próprio sentido do Brasil enquanto nação. E para isso era fundamental distinguir muito bem os africanos tanto dos cidadãos brasileiros quanto dos estrangeiros, mesmo que à época ainda não houvesse uma legislação sistemática a respeito das relações do Brasil com os não "nascidos no Brasil", ${ }^{13}$ o que torna a questão da cidadania um problema eminentemente político e não jurídico.

Essa diplomacia dissimulada negocia com as palavras, com a polidez da língua política e cria, como efeito de real, como dedução constativa, o espaço da rejeição dos (agora) inconvenientes "hóspedes traiçoeiros" ${ }^{14}$ pelo recurso àquela alteridade proibida, não negociável, não conciliável. Enquanto se esperava dos escravos obediência, estes respondiam com a insurreição e a rebeldia. Enquanto se esperava dos libertos a gratidão pela benevolente (possibilidade da) alforria, estes respondiam com conspirações, com a imperdoável solidariedade e mesmo com participações diretas nas insurreições escravas. Daí a dupla preocupação das autoridades baianas depois de 1835: o corpo cativo, força de trabalho e instrumento de produção era potencialmente hostil; o corpo liberto, forro, não era mais útil ("não utilizam nada o Paiz com sua estadia", como disse o chefe de polícia).

Mas para além do ressentimento, a carta do presidente da província articula sob a transparente homogeneidade e completude, discursividades ${ }^{15}$ que embora atravessadas possuem especificidades. Eu gostaria, portanto, de segmentar o fragmento supracitado em duas sequências discursivas ${ }^{16}$ distintas para dar visibilidade aos processos de encaixe/articulação que garantem o efeito de horizontalidade entre esses enunciados:

${ }^{13}$ A legislação sobre o estrangeiro só é desenvolvida sistematicamente no século XX, em 1980.

14 "Hóspedes? Tinham os africanos por acaso atravessado o Atlântico como convidados, de livre vontade? A inadequação do termo era escandalosa, mas perfeitamente adequada à ideologia escravocrata. O comportamento dos libertos parecia particularmente imperdoável, pois eles representariam no imaginário senhorial uma prova viva do liberalismo e da benignidade da escravidão no país, que permitia e facilitava a obtenção da alforria. Aquela "traição", em contrapartida, criava uma excelente oportunidade para se dar início a um efetivo programa de desafricanização da sociedade baiana. No discurso condescendente das autoridades, as deportações legais não eram motivo de culpa, porque os africanos, afinal, haviam se mostrado tão antinacionais que não mereciam o privilégio de viver no país" (Reis, 2003, pp. 477-478)

15 Quando falo em discursividade faço referência à língua funcionando enquanto base material (equívoca) atravessada pela história (contraditória).

16 Em Courtine, as sequências discursivas (Sd) são definidas como as "sequências orais ou escritas de dimensão superior à frase" (Courtine, 2009, p. 55). Aqui, no entanto, procuro trabalhar as Sd na articulação entre base (linguística) e processo (discursivo), ou seja, não por sua extensão, mas pelo funcionamento interdiscursivo da sequência na sua relação com o corpus. Considero, então, certas construções linguísticas pinçadas do corpus como indícios, pontos de partida de funcionamentos discursivos, trabalhando-as nos pontos de articulação entre língua e história. Distinta de uma sequência linguística a Sd aponta para a construção na sua materialidade, isto é, nas múltiplas determinações que constituem a sua espessura histórica. Ver Henry (1990) para uma análise minuciosa das relações entre língua e discurso. Para uma caracterização dos critérios de segmentação de um corpus em sequências discursivas, ver Lima, 1990. 
$\left(\mathrm{Sd}_{1}\right)$ Não sendo os africanos libertos nascidos no Brasil e possuindo uma linguagem, costumes $e$ até religião diferente dos brasileiros e pelo último acontecimento declarando-se tão inimigos da nossa existência política $[\ldots]$

$\left(\mathrm{Sd}_{2}\right)[\ldots]$ eles não podem jamais ser considerados cidadãos brasileiros para gozar das garantias afiançadas pela Constituição

Parto, então, da hipótese de que a $\mathrm{Sd}_{1}$ e $\mathrm{Sd}_{2}$ organizam, no intradiscurso, dois domínios de memória ${ }^{17}$ distintos: o primeiro, tematiza fundamentalmente a distinção entre africanos e brasileiros a partir de um conjunto de diferenças simétricas que funciona, textualmente, como a justaposições de argumentos, de asserções coordenadas típico do discurso colonizador. ${ }^{18} \mathrm{O}$ segundo, parte de um princípio jurídico (a cidadania) e um instrumento (a Constituição de 1824) para assegurar essas diferenças, afirmar que o cidadão brasileiro é aquele que pode "gozar das garantias afiançadas pela Constituição" e, além disso, especificar quais as distinções negociáveis entre aqueles que jamais podem ser considerados cidadãos brasileiros e aqueles que, sob certas condições, podem (ou devem). Essa divisão garante, no quadro da formação discursiva antiafricana, o regime de alteridades que constitui ao mesmo tempo um projeto de nação (de Brasil) e a legitimidade da cidadania (e do cidadão brasileiro), aquela que garante tanto o acesso às "garantias afiançadas pela Constituição" quanto a existência política (já significada enquanto existência legítima) do indivíduo. ${ }^{19} \mathrm{E}$ se "um aspecto importante do discurso colonial ${ }^{20}$ é sua dependência do conceito de 'fixidez' na construção ideológica da alteridade" (BHABHA, 1998, p. 105), veremos pelo viés da memória, do discurso e da contradição (e não pelo viés dos "costumes" ou "identidades" em conflito) como essa fixidez constrói intradiscursivamente as relações de diferença e igualdade.

${ }^{17}$ Courtine, 2009.

18 Bhabha, 1998.

${ }^{19}$ Aqui a formação discursiva será mobilizada para significar o lugar onde se constitui o sujeito (enquanto sujeito do "seu" discurso, ou seja, da ilusão subjetiva) na medida em que "é no interior de uma FD que se realiza o 'assujeitamento' do sujeito (ideológico) do discurso” (Courtine, 2009, p. 73) e, ao mesmo tempo, para significar uma região do interdiscurso submetida a relações de dominância, subordinação, alianças e rupturas. Essa compreensão parte da releitura operada por Michel Pêcheux, Claudine Haroche e Paul Henry do conceito de formação discursiva proposto e definido por Michel Foucault na sua Arqueologia do saber. Assim, a formação discursiva antiafricana é, ao mesmo tempo, um espaço de identificação que constitui o efeito subjetivo e uma região onde nomes, construções e enunciados estão disponíveis para serem mobilizados - de forma não intencional/instrumental - pelos sujeitos interpelados e identificados por essa formação discursiva.

${ }^{20}$ Creio que podemos pensar, mesmo no cenário pós-independência, no império brasileiro, em um discurso colonial, compreendendo-o como um discurso que estabelece uma consignação da alteridade, um confisco da palavra do outro e busca instituir e condensar sentidos por um apagamento da história que é, no fim das contas, um efeito de inscrição de outra história no arquivo. Prefiro pensar, no entanto, esses enunciados enquanto elementos de um discurso colonizador. Diferentemente de discurso colonial, colonizador aponta para o processo, para a colonização e não apenas para a colônia enquanto resultado. 
Assim, podemos fragmentar, por paráfrases, a $\mathrm{Sd}_{1}$ para dar visibilidade às articulações próprias a essa discursividade:

$\left(\mathrm{Sd}_{1.1}\right)$ Os africanos libertos não são nascidos no Brasil

$\left(\mathrm{Sd}_{1.2}\right)$ Os africanos libertos não possuem uma linguagem igual à dos brasileiros

$\left(\mathrm{Sd}_{1.3}\right)$ Os africanos libertos não possuem costumes iguais aos dos brasileiros

$\left(\mathrm{Sd}_{1.4}\right)$ Os africanos libertos [até] não possuem uma religião igual à dos brasileiros

$\left(\mathrm{Sd}_{1.5}\right)$ Os africanos, pelo último acontecido, declararam-se [tão] inimigos da existência politica $\left\{\frac{\text { do brasil }}{\text { dos brasileiros }}\right\}$

O inventário de diferenças textualizado como um conjunto de predicações (que vai da $\mathrm{Sd}_{1.1}$ à $S d_{1.4}$ ) dissimula sob a estrutura regular da negação (x não é y) outros enunciados inscritos, mas não escritos, que não figuram no intradiscurso, mas são constitutivos dessas textualizações. Ou seja, na $\mathrm{Sd}_{1}$ enunciados laterais, subjacentes, dizem os enunciados silenciados ${ }^{21}$ pela negação. Assim, a despeito do apelo constativo, dizer "os africanos não são nascidos no Brasil" não implica apenas dizer "os africanos são nascidos em outro lugar", mas também "os africanos $\left\{\frac{\text { não são }}{n a ̃ o \text { poderão jamais ser considerados }}\right\}$ cidadãos brasileiros", pelo menos desde a Constituição de 1824. Esse desdobramento tem uma consequência importante. Se, na formulação "não sendo os africanos libertos nascidos no Brasil", "não nascidos no Brasil" for justificativa para "não podem jamais ser considerados cidadãos brasileiros para gozar das garantias afiançadas pela Constituição", o enunciado contraria o imperativo jurídico, na medida em que "estrangeiros naturalisados" (que também "são nascidos em outro lugar") podem ser cidadãos brasileiros. Vejamos o que diz a constituição do império, especificamente os incisos primeiro e quinto:

\section{TITULO $2^{\circ}$}

Dos Cidadãos Brazileiros.

Art. 6. São Cidadãos Brazileiros

I. Os que no Brazil tiverem nascido, quer sejam ingenuos, ou libertos, ainda que o pai seja estrangeiro, uma vez que este não resida por serviço de sua Nação.

II. Os filhos de pai Brazileiro, e Os illegitimos de mãi Brazileira, nascidos em paiz estrangeiro, que vierem estabelecer domicilio no Imperio.

III. Os filhos de pai Brazileiro, que estivesse em paiz estrangeiro em sorviço do Imperio, embora elles não venham estabelecer domicilio no Brazil.

IV. Todos os nascidos em Portugal, e suas Possessões, que sendo já residentes no Brazil na época, em que se proclamou a Independencia nas Provincias, onde habitavam, adheriram á esta expressa, ou tacitamente pela continuação da sua residencia.

V. Os estrangeiros naturalisados, qualquer que seja a sua Religião. A Lei determinará as qualidades precisas, para se obter Carta de naturalisação.

\footnotetext{
${ }^{21}$ Orlandi, 2007a.
} 
O inciso primeiro afirma categoricamente que não basta apenas ter nascido no Brasil para que a garantia à cidadania seja assegurada. Para além da elipse que coloca problemas ligados ao pré-construído ${ }^{22}$ (“Os [ $\mathbf{\Delta}$ ] que no Brazil tiverem nascido...”) há um impedimento àqueles " $o s$ " que, por exemplo, nascessem de pais que, embora no Brasil, estivessem trabalhando por seu país à época. ${ }^{23}$ Mas este é o único impedimento que atinge os nascidos no território brasileiro. Ao mesmo tempo, o fato de não ter nascido no Brasil também não impede que "nascidos em outro lugar" obtenham uma "carta de naturalisação". É a possibilidade da naturalização que garante, então, uma cidadania consignada, que transcende o imperativo territorial (expresso pelo "nascidos em outro lugar") e define na lei o espaço da alteridade possível, permitida ou negociável no campo do político. Aqui podemos observar, de maneira mais incisiva, a negação como uma formulação saturada, que condensa um enunciado subjacente e divide o regime de alteridades da seguinte maneira:

$\left(\mathrm{Sd}_{3}\right)$ Eles $\left\{\frac{\text { poderão [sob certas condições] }}{\text { jamais poderão }}\right\}$ ser considerados cidadãos brasileiros

Temos, então, uma tensão entre as seguintes paráfrases possíveis: " $O s$ não nascidos no Brasil jamais poderão ser cidadãos brasileiros" e "nem todos não nascidos no Brasil jamais poderão ser cidadãos brasileiros" ou "alguns não nascidos no Brasil poderão ser cidadãos brasileiros". Uma tensão, portanto, em torno desse "eles" (daquela elipse mencionada acima) que mobiliza o pré-construído no intradiscurso. Esse intervalo tensiona, no interdiscurso, a diferença entre africano e estrangeiro, reforçando a necessidade de determinar quem são os "nascidos fora do Brasil" que interessam ao país. Essa extensão jurídica do dizer político tangencia o que chamei de cidadania consignada ao negar, além da cidadania, a possibilidade da cidadania (a partir, por exemplo, de paráfrases como "Os africanos não podem obter jamais uma carta de naturalização" ou "os africanos não podem jamais ser cidadãos brasileiros"). Assim, essa articulação do político com o jurídico transforma, de saída, diferença em desigualdade. Foi isso que busquei chamar logo acima de espaço do inegociável, inconciliável, dividido

${ }^{22}$ De acordo com Michel Pêcheux, o pré-construído (ou o efeito de pré-construído) é um funcionamento discursivo "ligado ao encaixe sintático" (Pêcheux, 2009, p. 89). Associado às relativas restritivas, ele designa, num enunciado, "o que remete a uma construção anterior, exterior, mas sempre independente, em oposição ao que é ‘construído’ pelo enunciado” (idem). O conceito procura trabalhar o impasse lógico e semântico em torno da relação entre sentido e referência, sobretudo quando o que está em jogo são os chamados pressupostos existenciais a partir de uma crítica à compreensão referencialista do pressuposto. Pêcheux propondo uma instabilidade/equivocidade constitutiva do referente sustentada na relação da língua com o interdiscurso, o " todo complexo com dominante' das formações discursivas" (Pêcheux, 2009, p.149) cujos objetos não existem independentemente da sua inscrição histórica, mas são sempre produzidos em formações discursivas (Pêcheux, 2011a). Há em Paul Henry $(1990 ; 1992)$ um largo e incontornável debate em torno dessas questões.

23 Guimarães (1996) vai fazer uma análise do artigo "os" como anáfora e como dêitico, para apontar que a ambivalência da elipse impõe uma quebra na construção "cidadão brasileiro" e dá visibilidade às palavras "cidadão" e "brasileiro", que não aparecem, no entanto, sozinhas na Constituição e que estão, ambas, determinadas por "súditos". 
por um regime de diferenças que não é apenas de distinções, que poderiam se conciliar, se equacionar ao escopo da cidadania (inclusive do ponto de vista jurídico via "naturalisação"), mas uma diferença que é (e sempre será, conforme aponta o advérbio "jamais") intrinsecamente desigual e não equacionável no repertório da formação discursiva antiafricana que orienta o discurso das autoridades baianas no século XIX.

Quanto à $\mathrm{Sd}_{1.5}$ podemos, mesmo sob o risco de ignorar o advérbio "tão" (fundamental como índice dessa desigualdade não-conciliável), parafraseá-la como "Os africanos, pelo último acontecimento, declararam que não são amigos da existência política $\left\{\frac{\text { do brasil }}{\text { dos brasileiros }}\right\}$ " para dar ênfase tanto à ambivalência da anáfora (garantida porque o pronome "nosso" pode retomar correferencialmente tanto "Brasil" quanto "brasileiros") quanto para pensar essa relação a partir da negação, que é uma regularidade no pronunciamento e é permitida pela sinonímia "inimigo" $\leftrightarrow$ "aquele que não é amigo" ou ainda pela paráfrase "inimigo" $\rightarrow$ "aquele que se opõe".

Esse efeito faz ressoar no interdiscurso uma relação com o artigo primeiro da Constituição de 1824, aquele que define o império e, ao mesmo tempo, circunscreve o sentido político do "Cidadão Brazileiro":

Art. 1. O IMPERIO do Brazil é a associação Politica de todos os Cidadãos Brazileiros. Elles formam uma Nação livre, e independente, que não admitte com qualquer outra laço algum de união, ou federação, que se opponha á sua Independencia.

$\mathrm{Na}$ Constituição (mas também na carta do presidente da província) o registro das diferenças se faz pelo recurso ao que Michel Pêcheux chama de língua de Estado, uma discursividade onde "o dizível e o existente devem coincidir sem falha" (PÊCHEUX, 2011a, p. 86), cujo funcionamento espelha o real no arquivo e condensa as contradições em dessemelhanças que podem ser "resolvidas" no campo do jurídico ou na língua de madeira da política. A lei de 1824, definindo o Brasil como "associação Politica de todos os Cidadãos Brazileiros", define também o africano como o inexistente/irrealizado da formação social brasileira, aquele que não faz parte da associação política composta por "elles", os cidadãos brasileiros. De modo ainda mais direto, o artigo primeiro diz que o africano não faz parte do império, não possui nenhum direito político (ou mesmo existência política) e, como bem enfatizou o presidente da província, não goza "das garantias afiançadas pela Constituição": uma delas é a própria possibilidade de obtenção da cidadania consignada pelo direito à naturalização.

Mas talvez o mais fundamental do ponto de vista de uma consequência política e jurídica da definição de Império seja o fato de que ele é compreendido como uma associação política que é livre e independente. Diferentemente de cidadão e brasileiro, que só aparecem na construção determinada "cidadãos brasileiros", "Império" e "Brazil" possuem existência autônoma no intradiscurso e estabelecem, inclusive, relações correferenciais. Na medida em que os africanos são significados como "inimigos da existência política do Brasil" é também contra o próprio império (enquanto "associação política") e, consequentemente, contra “todos os Cidadãos Brazileiros”, que eles são significados. 
Antes de prosseguir à análise dos enunciados, gostaria de fazer uma observação conceitual e heurística que toca a articulação entre o funcionamento interdiscursivo e intradiscursivo dessas formulações, sobretudo a respeito da notação fracionada $\left(\left\{\frac{x}{y}\right\}\right)$ de certas sequências e paráfrases que venho utilizando e que dialoga com o que Jean-Jacques Courtine ${ }^{24}$ denomina enunciado dividido. Partindo da compreensão de que um dos traços (ou efeitos) do discurso político é a construção de objetos sem fronteira, lógicos, originários e idênticos a si mesmo, achei interessante pensar na formação dos objetos a partir, justamente, da demarcação dessas fronteiras no gesto descritivo-interpretativo. Ao invés de pensar, então em condensação ou saturação, me veio (não o conceito deleuziano, mas) o processo empírico-artesanal da dobra, da plissagem, que deixa marcas visíveis: o papel quando dobrado ou plissado guarda visíveis as marcas da dobra, as marcas da fronteira mesmo quando desdobrado. O dobrado joga também com o sentido de um duplo que não é apenas dois, mas não-um, que nega a linearidade, a horizontalidade. Dobra e desdobra vem fazer frente a um efeito ou gesto que não aparece de forma incisiva nas metáforas "químicas" da condensação e saturação. Assim, dizer dobrado (e não condensado, saturado etc.) é tanto dizer dividido, elidido, cindido quanto dar visibilidade, heuristicamente, ao efeito de fronteira pelo vinco oriundo desse processo. É, então, nesse sentido que o deslizamento "Imperio" ↔ "Brasil" e "Império" $\rightarrow$ "todos os cidadãos Brazileiros" permite desdobrar a seguinte paráfrase:

$\left(\mathrm{Sd}_{4}\right)$ Os africano são inimigos $\left\{\frac{\text { de todos os cidadãos brasileiros }}{\text { do império }}\right\}$

Nesse caso, ser inimigo da existência política $\left\{\frac{\text { do brasil }}{\text { dos brasileiros }}\right\}$ encorpa o conjunto de diferenças inegociáveis, que transcendem as diferenças linguísticas, culturais e religiosas para instituir o africano como um elemento hostil social e politicamente. É aqui que podemos notar que a despeito advérbio "até", elemento que enfatiza a diferença religiosa como um agravante da não conciliação entre africanos e cidadãos brasileiros, a compreensão mais ampla dessa alteridade rejeitada mostra que o problema fundamental não é de ordem religiosa. Essa relação parece apontar para uma não-coincidência da sintaxe no discurso, na medida em que uma explicação sintática não dá conta de compreender como elemento "agravante" (no intradiscurso) figura como uma dissimulação (no interdiscurso). Isso quer dizer, fundamentalmente, que o problema mais grave não é (qualquer) outra religião, mas as religiões africanas, do mesmo modo que o impedimento de obtenção da cidadania brasileira não é ser "nascido fora do Brasil", mas ser "nascido na África". Aqui a questão religiosa (que é acentuada na discursividade política) faz parte do repertório das diferenças inegociáveis, segue a regularidade de uma diferença que não é só outra (ou diferente), mas africana, étnica e racial. Isso está bastante mais visível na lei provincial $\mathrm{n}^{\circ} 9$, de 13 de maio de 1835. Ali é quase evidente a relação antagônica entre a fé africana e a "Religião

${ }^{24}$ Courtine, 2009. 
Christâa" a partir de um efeito de (in)submissão que significa a fé africana como potencialmente insubmissa sendo, portanto, necessária a imediata conversão dos africanos. A lei dizia que os "senhores de africanos hauçaes procurarão, pelos meios lícitos, instruil-os nos mysterios da Religião Christã e baptizal-os, incorrendo na mulcta de cincoenta mil réis por escravo pagão, que existir seis mezes depois da publicação desta Lei, aquelle senhor, que, á juizo do respectivo Parocho, e Juiz de Paz do districto, fôr julgado negligente".

Cabe fazer uma observação a respeito dessas relações para não corrermos o risco de saturar um conjunto de determinações históricas que se articulam na conjuntura singular da Bahia oitocentista sob o signo do "conflito cultural", o que transformaria uma contradição intrinsecamente não-sintetizável em "antagonismo" ou "desajuste". Creio que esse ponto de vista sustenta uma compreensão do político como espaço de construção do consenso, de articulação do comum (que não pode escapar da ideologia jurídica do bem-comum) e do social como campo homogêneo, do entendimento e razoabilidade, onde as diferenças devem ser de tal maneira que, embora reconhecidas, não atrapalhem o arranjo ou a harmonia daqueles que, civilizados e razoáveis, decretam e legislam sobre e sob os sentidos de arranjo e harmonia. Paralelamente, os outros, os outsiders, ${ }^{25}$ são aqueles que não conseguem se adaptar a um espaço tal de exigências restando à revolta o único espaço legítimo de negociações com o poder instituído. Nesse campo, os conflitos são duelos, disputas compreendidas no campo humanista das heterogeneidades empíricas ou ainda no campo sociologista dos "conflitos lógico-éticos e psicológicos que participam da essência humana da sociedade" (PÊCHEUX, 2011c, p. 180). É dessa maneira, sobretudo, que o ponto de vista do "conflito cultural" satura o ideológico nos "costumes" ignorando uma compreensão da revolta como resistência, ${ }^{26}$ como aquilo que fura a ordem do discurso e põe à prova a sensatez do enunciado político, os fundamentos das relações sociais, os frágeis suportes da "civilização" e a obsessão do jurídico na construção de um social lógico e transparente.

Se, como mencionado, há uma admissão das diferenças é pelo viés da "ambiguidade", da "possibilidade" do não-um, mas jamais de uma ambivalência, que considera o não-um como constitutivo. A ambivalência própria à contradição desorganiza as bases da diferença e reconfigura, como um processo de jogo (com) o (in)tangível, como uma forma de atribuir sentidos tanto ao possível quanto ao impossível por meio de uma outra forma de significar a composição das relações sociais. É por isso que a revolta desorganiza, inverte, parodia, obriga o adversário a significar relações fora do esperado, do prescrito mesmo em uma situação de consignação da fala pelas instâncias oficiais (sobretudo os documentos produzidos pelas instituições) que produzem uma espécie de fala verdadeira que tem direito de circular e de fazer circular o dizer do outro.

\footnotetext{
${ }^{25}$ Elias; Scotson, 2000.

${ }^{26}$ Pêcheux, 1990.
} 
A revolta é, portanto, oficiosa, da ordem da ginga, funciona nos meandros da oficialidade como uma paráfrase nem sempre textualizada das relações ordinárias, entendidas aqui como relações da organização e não da ordem. ${ }^{27}$ Ela é aquilo que, como acontecimento, instaura uma dobra, uma falha, uma esquiva, um regime singular de memória, retomadas, antecipações, que mesmo silenciada ganha forma nos interstícios das negações, nas anáforas, nas aposições como aquilo que desdobra, como o ponto do des-ligamento, como o espaço histórico-linguístico das articulações, como aquilo que permite a fratura da sintaxe e do texto, aquilo que quebra a horizontalidade unilinear do sintagma, dividindo-o, expondo-o à sua unidade impossível. ${ }^{28} \mathrm{Ou}$ seja, mesmo que a revolta reforce ainda mais a tirania do arquivo (a palavra consignada por aqueles que detêm os meios de inscrição, inventariação e circulação documental), ela dá visibilidade a uma espécie de lateralidade inconveniente, oriunda justamente dessa não-unidade expressa pela horizontalidade da sintaxe.

Partir desse princípio, do lugar do "cultural", é significar a revolta a partir do arranjo próprio ao imaginário político/jurídico, que enquadra no espaço do discurso institucional (seja ele diplomático, jurídico, administrativo) o irreconciliável, o alhures, o impossível, transformando o intangível em um conjunto de demandas que reduz a complexidade contingente da resistência e da contradição a um confronto entre duas unidades homogêneas, diferentes apenas quando expostas a uma relação de oposição, diferentes apenas um do outro. Gostaríamos de compreender a revolta a partir de um outro ponto de vista, como o ponto de convergência entre memórias/discursividades inegociáveis, irreconciliáveis, contraditórias que assumem, no arquivo, a forma de um litígio entre o possível e o impossível, entre o tangível e o intangível.

A contradição, cabe precisar, é entendida aqui a propósito da língua, enquanto princípio que a faz funcionar como unidade dividida. ${ }^{29}$ Esse modo de compreender a contradição (que Louis Althusser chama de contradição desigual) distingue-a da contradição simples "que opõe duas entidades iguais, simplesmente anexadas do signo contrário" (ALTHUSSER, 1978, p. 147). Ou seja, essa não uma contradição que opera ou agencia elementos opostos ("cidadãos brasileiros" e "africanos", por exemplo), como se esses elementos possuíssem homogeneidade ou fossem invariantes originários, ${ }^{30}$ mas uma contradição que supõe unidades divididas. A partir uma posição discursiva, ${ }^{31}$ esse ponto de vista considera a divisão-desigualdade do sentido como fundamento das relações semânticas e não como mero acidente ou casualidade de certas construções ou palavras "ambíguas".

\footnotetext{
27 A respeito da distinção entre ordem (real) e organização (imaginária) ver Orlandi, 1999.

${ }_{28}$ O debate em torno das relações de coordenação é explorado em Pêcheux, 2016b.

29 Pêcheux, 2011c.

30 No mesmo texto, Althusser afirma que "todo começo é marcado pela desigualdade"
} (Althusser, 1978, p. 148)

31 E aqui me refiro, sobretudo, à intervenção de Michel Pêcheux no quadro teórico e conceitual do marxismo. Marxismo, por sua vez, já re-lido por Althusser. 
$\mathrm{O}$ fundamental para nós é sustentar que os elementos em jogo ${ }^{32}$ são, portanto, contraditórios em si mesmos, diferentes em sua unidade, e não apenas em uma relação diferencial, principalmente porque o funcionamento do discurso não obedece ao primado da notação lógica das línguas artificiais, mas ao litígio oriundo de uma articulação constitutiva da materialidade linguística ao real da história. Isso significa assumir que há um primado da não-identidade do sentido que impede à língua em funcionamento estar submetida, como salienta Pêcheux, ${ }^{33}$ ao conceito lógico de "axioma de identidade": o sentido está, desde sempre, investido no campo do paradoxo. ${ }^{34}$

Compreender que a contradição desigual constitui a língua é, também, considerar tanto o significante (os pré-construídos enquanto "objetos" disponíveis à textualização) quanto as construções (des-ligamento/encaixe, sustentação/ articulação) a partir de um efeito de horizontalidade que garante, no imaginário, a sua homogeneidade, completude e finitude. Essa contradição, cabe precisar, é constitutiva enquanto forma histórica de existência das unidades, mas os seus contrários são conjunturais, contingentes. Assim, os sentidos de "africano" (ou de "inimigos") não está submetido às mesmas divisões ou fraturas de sentido no século XVI e no século XIX, por exemplo, embora esteja, desde sempre, diante de uma contradição desigual. Não existe signo, construção ou texto unívoco, mesmo que os contornos singulares dessa abertura do sentido dependam de um efeito conjuntural que o circunscreve: o sentido "não está fixado a priori como essência das palavras, nem tampouco pode ser qualquer um" (ORLANDI, 2007a, p. 27).

Essa perspectiva evita conceber a disputa enquanto um binômio mecânico sem história (que é, no fim das contas, a posição do presidente da Província) e nos permite compreender a relação entre o poder político e os africanos libertos a partir de uma luta por sentidos que só é textualizada, documentada e inventariada por um lado, embora as discursividades em cena se atravessem pelos modos específicos de se apropriar do discurso do adversário, ${ }^{35}$ seja por consignação, interdição ou apagamento. Essa massa documental significa/sintetiza a contradição pelo confisco de um possível, pela ratificação de um inexistente/ irrealizável, acomodando semanticamente essa contradição e revestindo-a de uma discursividade que incorpora como sempre-já-lá, como forma evidente, o dizer das instituições, saturando uma síntese impossível nos interstícios do jurídico e do administrativo. A língua de Estado horizontaliza e condensa um conjunto de determinações que possuem temporalidades próprias (cidadania, língua, costumes e religião) e dominância variável na formação discursiva antiafricana/ antinegra. Expor a não horizontalidade e não homogeneidade da sintaxe/texto é fundamental para dar visibilidade às transversalidades, às distintas discursividades que atravessam, recortam, desdobram, compõem o documento e, que ao mesmo tempo, transcendem tanto o "fato" quanto o "referente".

32 É importante ressaltar também que embora a contradição desigual seja a-histórica, o jogo tem sua história, ou seja, não são todos os elementos que podem estabelecer uma relação diferencial.

${ }^{33}$ Idem.

34 Pêcheux, 2011a; Zoppi-Fontana, $2005 b$.

35 Pêcheux, $2016 a$. 
Recusar uma interpretação do antiafricanismo e do inventário das diferenças como um problema ou conflito "cultural" significa também partir de uma perspectiva descentrada, que trabalha a relação da língua com a sua exterioridade constitutiva - o interdiscurso - e não busca estabelecer conexões entre "fato" e "documento". É por isso que estamos compreendendo tanto o discurso das autoridades quanto as leis como gestos de interpretação já atravessados pelo imaginário. $\mathrm{O}$ que nos interessa, portanto, não é buscar as causas dos fatos nos documentos, mas as formas pelas quais a contradição é significada e o modo com imbricam, articulam, condensam memórias. São essas relações que fazem que ultrapassemos o domínio do "fato" para pensar o acontecimento discursivo como um espaço que produz, desorganiza, dobra e rasura os sentidos. ${ }^{36}$

Creio que posso, então, apontar as consequências da hipótese inicial: o pronunciamento do presidente da província condensa (ou encaixa) o discurso político $\left(\mathrm{Sd}_{1}\right)$ no discurso jurídico $\left(\mathrm{Sd}_{2}\right)$ como uma decorrência lógica, como uma consequência inexorável. Essa condensação dissimula, no intradiscurso, a passagem ou costura entre duas discursividades distintas que aparecem saturadas na sequência horizontal como pura "sucessão de argumentos" ou "justaposição de ideias". Mas se "as ideias só possuem existência histórica quando pegas e incorporadas à materialidade das relações sociais"37 (ALTHUSSER, 1978, p. 204) é fundamental compreender essa sequência nas relações que ela estabelece com outras sequências no interdiscurso, todas afetadas (de maneiras distintas) por uma série de determinações.

Gostaria de salientar, por ora, uma dessas determinações: a construção de um outro-hostil, memória constitutiva do imaginário baiano (e brasileiro) que impõe ao poder político a necessidade de textualizar os seus conflitos e necessidades (o campo do político, em suma) pela narrativa do inimigo, do "eles" antagonista que pode a qualquer momento colocar o "nós" e o "nosso" em risco. Desde o século XVI, com a formação da cidade de Salvador pela relação tensa com os povos indígenas, esse outro-hostil é construído pelo apagamento dos processos que o constituem e que constituem, sobretudo, a sua relação antagônica com o poder político. Ou seja, é essa relação com a exterioridade (e não a sintaxe) que agencia o encaixe/articulação dos enunciados (e não apenas de dois "pensamentos" ou "argumentos") como uma materialidade supostamente homogênea, mas que sustenta esse entremear do jurídico com o político como evidência da alteridade e da semelhança (im)possível e (irre)conciliável.

Gostaria, a partir dessas observações, de me deter, na $\mathrm{Sd}_{2}$ :

$\left(\mathrm{Sd}_{2}\right)$ eles [os africanos] não podem jamais ser considerados cidadãos brasileiros para gozar das garantias afiançadas pela Constituição.

\footnotetext{
${ }^{36}$ A respeito da relação entre "fato" e acontecimento discursivo, ver Pêcheux, 2006.

${ }^{37}$ Tradução minha. No original: "Les idées n'ont d'existence historique que si elles sont prises et incorporées dans la matérialité des rapports sociaux".
} 
O mais curioso dessa formulação é que definindo os "cidadãos brasileiros" como aqueles que podem "gozar das garantias afiançadas pela constituição", ela circunscreve (por uma retomada da $\mathrm{Sd}_{1}$ ) os "cidadãos brasileiros" tanto como aqueles que compartilham linguagem, costumes e religião comuns (e que por isso podem "gozar das garantias afiançadas pela Constituição") quanto como aqueles que não se declaram inimigos da existência política do Brasil e dos demais cidadãos brasileiros, aqueles que compõem o império. Novamente aqui o "nós" político faz laço e determina esse sítio de identificações e coesão no campo do social e do político, instituindo o outro-hostil como alteridade irrealizável, inclusive no campo do jurídico. Podemos pensar, portanto, na seguinte paráfrase, onde uma conjunção articularia essas duas discursividades:

$\left(\mathrm{Sd}_{5}\right)$ Os africanos não podem jamais ser considerados cidadãos brasileiros para gozar das garantias afiançadas pela Constituição pois não são nascidos no Brasil, não possuem uma linguagem, costumes e até religião iguais dos brasileiros, e pelo último acontecimento, declararam-se [tão] inimigos da nossa existência política.

Como fiz questão de mencionar acima, a articulação de enunciados não é um fenômeno exclusivamente sintático, mas um processo que faz convergir no intradiscurso enunciados cujas temporalidades diferenciais ${ }^{38}$ impõem uma decalagem, uma não horizontalidade do sentido, uma heterogeneidade na suposta homogeneidade do sintagma e do texto. $\mathrm{O}$ "pois" articula, conforme antecipado, não apenas dois enunciados, mas dois discursos distintos. Esse conjunto de precisões gera um efeito explicativo que é "os africanos, aqueles que [ $\mathbf{\Lambda}$ ], não podem jamais ser cidadãos brasileiros" onde a elipse condensa e articula todo aquele conjunto de determinações, negações e predicações que constituem "a evocação lateral daquilo que se sabe a partir de outro lugar" (PÊCHEUX, 1997, p. 111).

Tomemos, como exemplo desse funcionamento, um enunciado presente em Frege, ${ }^{39}$ retomado e analisado por Pêcheux. ${ }^{40}$ A respeito do enunciado científico "O gelo, que tem um peso específico inferior ao da água, flutua sobre a água" podemos dizer que o que articula os enunciados "O gelo flutua sobre a água" e "O gelo tem um peso específico inferior ao da água" é uma premissa, ou melhor, um axioma químicofísico que permite, caso nos perguntemos sobre as condições de possibilidade desse encaixe, responder: "Se alguma coisa tem um peso específico inferior ao da água, [essa coisa] flutua sobre a água". Ou seja, entre os dois enunciados há um terceiro, uma evocação exterior e independente que sustenta a articulação entre os dois, garantindo uma conjunção explicativa, como em "o gelo flutua sobre a água, pois tem um peso específico inferior ao da água". A conjunção remete, portanto, a articulação a um enunciado exterior ("tudo aquilo que tem um peso específico inferior ao da água, flutua sobre a água") como efeito de evidência.

\footnotetext{
${ }^{38}$ A respeito do conceito de temporalidade diferencial ver Althusser, 1965.

39 Frege, 2009.

${ }^{40}$ Pêcheux, 2009.
} 
Igualmente, em "os africanos não podem jamais ser considerados cidadãos brasileiros pois [ $\mathbf{\Delta}$ ]" há uma remissão a um conjunto de elementos que intervêm como aquele "terceiro enunciado" (no caso, "todos aqueles que não [ $\mathbf{\Lambda}$ ] não podem ser jamais ser considerados cidadãos brasileiros"), exterior e independente, que articularia "os africanos" a "não podem jamais ser considerados cidadãos brasileiros" produzindo, por exemplo, uma paráfrase explicativa como "os africanos, aqueles que [ $\mathbf{\Delta}]$, não podem jamais ser considerados cidadãos brasileiros". Partindo desse cenário, temos o seguinte desdobramento da formulação:

$\left(\mathrm{Sd}_{6}\right)$ Os africanos, que [ $\left.\mathbf{\Lambda}\right]$, não podem ser jamais ser considerados cidadãos brasileiros $\left(\mathrm{Sd}_{6.1}\right)$ Os africanos não podem jamais ser considerados cidadãos brasileiros

$\left(\mathrm{Sd}_{6.2}\right)$ Os africanos não $[\mathbf{\Delta}]$

$\left(\mathrm{Sd}_{6.3}\right)$ Todos aqueles que não $[\mathbf{\Lambda}]$ não podem ser jamais ser considerados cidadãos brasileiros

O que eu pretendo, assemelhando o enunciado científico ao enunciado político é dar visibilidade ao modo como cada discursividade recorre, no seu exterior específico, aos pré-construídos, aos "objetos" e aos modos de encaixe das suas asserções. Acontece que diferentemente do enunciado científico, não existe uma "axiomática política" que validaria, de saída, os argumentos políticos por dedução ou, de modo mais claro, que permitiria que os enunciados fossem encaixados por critérios de validação experimental/conceitual. As justificações e explicações que compõem os axiomas do discurso político são, sem meias palavras, o puro espaço do imaginário, da ideologia (compreendida aqui como uma estrutura que produz evidências para o sujeito), que recupera "objetos" na maioria das vezes do discurso jurídico enquanto instância normativa e fiadora do enunciado político na luta dessas asserções contra o abstrato, o infundado e o absurdo. Esse efeito de evidência que permite que as premissas sejam ao mesmo tempo as conclusões é puro efeito ideológico. E é esse puro efeito ideológico que sustenta a maior parte das formulações da formação discursiva antiafricana na Bahia oitocentista.

Antes de concluir uma interpretação, gostaria de me deter em outro trecho que vai na mesma direção. Uma resolução da Assembleia Legislativa da Província afirmou que "o espírito de rebelião e despeito que os libertos africanos acabem de manifestar neste País, requer imperiosamente que tratemos dos meios de restituilos à sua Pátria". ${ }^{41}$ É interessante observar aqui como "espírito de rebelião e despeito" condensa a alteridade impossível e como "requer imperiosamente que tratemos dos meios de restituí-los à sua Pátria" parafraseia "não podem jamais ser considerados cidadãos brasileiros" já, porém, embutindo uma solução ao reconhecimento do problema: a deportação. Afirma-se, ao mesmo tempo, que o Brasil não é nem a pátria dos africanos libertos e nem a pátria onde podem florescer "o espírito de rebelião e despeito". Há, na definição positiva do africano liberto, uma definição do cidadão brasileiro como aquele que não manifesta/não pode manifestar "o espírito de rebelião e despeito".

41 Resolução da Assembleia Legislativa Provincial da Bahia, citado por Reis, 2003, p. 479. 
É aqui, portanto, que o jogo de coordenações que encaixa enunciados exteriores ao intradiscurso apaga tanto a espessura histórica do caminho inverso dessa restituição (agora) necessária: o tráfico de escravos que floresceu, sobretudo na Bahia, mesmo após a proibição de 1831 e, de modo mais amplo, o próprio escravismo enquanto modo de produção dominante no Brasil. ${ }^{42}$ Assim, podemos parafrasear a resolução da seguinte maneira: "Devemos imperiosamente tratar dos meios de restituir os africanos libertos à sua Pátria pois eles acabaram de manifestar o espirito de rebelião e despeito neste País". A conjunção explicativa "pois" coordena, volto a afirmar, duas discursividades independentes: o primeiro diz "restituir à sua pátria" que tomo a liberdade de parafrasear, sem floreios, como "expulsar do Brasil". Era disso, afinal, que se tratava. Essa discursividade podia (e vimos, inclusive, como) articular diversas "razões". Uma delas é expressa pelo segundo enunciado, que explica a razão da expulsão pela "rebelião" e "despeito" que figuram como metáforas tanto da insurreição de janeiro quanto como o encaixe significante da memória da insubmissão negra/africana no texto, por uma significação dessa contradição inegociável a partir de uma imputação da responsabilidade dessas tensões única e exclusivamente dos africanos libertos. As autoridades, que por efeito metonímico significam também o império, se eximem de qualquer parte nessa relação. É curioso também o modo pelo qual o segundo enunciado ("eles acabaram de manifestar o espirito de rebelião e despeito neste País") entra em tensão com a justificativa presente na carta do presidente da província (elencadas no que chamei logo acima de "inventário de diferenças"), a não ser que se diga que a manifestação do "espírito de rebelião" seja oriunda justamente daquelas diferenças linguísticas, culturais e até religiosas.

Ou seja, dizer "devemos restituí-los à sua Pátria" é dizer, silenciando, "trouxemo-los da sua Pátria". Transpira no antiafricanismo o silêncio do próprio escravismo, o silenciamento dos corpos que foram (compulsoriamente) trazidos ao Brasil. Mas isso não interessa agora. O que interessa ao discurso político, ancorado nas prerrogativas jurídicas da cidadania/naturalização, é saturar a história das relações entre os africanos e o Brasil na hostilidade do "fato" (a rebelião), na hostilidade da memória (as rebeliões) e numa significação homogeneizante do africano (sobretudo o liberto) como insubordinado e perigoso. Talvez venha dessas múltiplas relações interdiscursivas a profusão de coordenações que insistem em inscrever no intradiscurso uma sucessão de razões: rebelião $e$ despeito; língua, costumes $e$ religião etc. Essa série de significações necessárias à desafricanização do Brasil horizontaliza, sobretudo, a contradição entre aqueles foram desde sempre - mas fundamentalmente agora - rejeitados enquanto pessoas (indivíduos, mas jamais cidadãos) e necessários como instrumento de produção, cuja existência de-pendia da/na balança operada pela tensão entre o poder político e o poder econômico. A emergência de um discurso que propõe a necessidade de configuração de um Brasil europeizado, civilizado, de acordo com o padrão desejado tanto pelas elites comerciais quanto pelo poder político vai acelerar e mobilizar uma extensa discursividade antiafricana que se organiza em torno de uma legislação ostensiva e intimidatória e uma profusão de rumores. E violência. Muita violência.

42 A respeito do escravismo como um “modo de produção” ver Gorender, 1978. 
É que a polícia não acompanhava e nem se interessava em dissimular a diplomacia dos púlpitos. Nas ruas da cidade os africanos passaram a ser humilhados, agredidos e mortos pela polícia, que contrariava mesmo a legislação, agindo de forma brutal contra a presença africana na cidade. $\mathrm{O}$ próprio chefe de polícia reconheceu que os "sucessos" da repressão tinham gerado abusos, "a um ponto tal que, hoje, já dão motivos sufficientes a queixas bem fundadas, pois que os soldados prendem, espancam e ferem, e mesmo matam os escravos que por mandado de seus Srs. vão á rua" ${ }^{43}$ O padre Étienne Ignace afirmou que "nem aos inocentes poupou a soldadesca encolerizada". ${ }^{44}$ Em uma das batidas rotineiras nas residências dos africanos, Torquato, de nação nagô, foi punido com 250 açoites $^{45}$ por terem sido encontrados em sua casa caixas que continham "uma volta de conta de vidros, com diferentes cores, uns pequenos breves cobertos de ouro contendo certas drogas com algodão desconhecidas, e em outros os cinco papéis". ${ }^{46}$ Outro africano liberto, Lobão, de nação nagô foi preso quase pelos mesmos motivos. Indignado, diz em seu julgamento que "ignora inteiramente o motivo porque foi prezo por isso que não tem culpa nenhuma nem fez crime algum" visto que sua casa foi "rigorosamente corrida abrindo-se lhe caixa examinando-se o que estava dentro, os seos balaios, e tudo o mais sem que, se lhe achasse coisa algua". Em sua casa foram encontrados "tres anneis de metal branco, e trez voltas de cordão de coiro com varios patuaes", "hu pequeno papel escripturado com letras harabicas" e mesmo "fragmentos de coisas insignificantes". ${ }^{47}$ Esse conjunto de coisas foi suficiente para que o africano fosse julgado culpado de ser "socio ou conivente na insurreição de pretos" mesmo que as testemunhas arroladas tenham afirmado desconhecer qualquer envolvimento de Lobão com a insurreição ou qualquer coisa que justificasse a sua prisão.

Como não eram cidadãos brasileiros, não tinham sua casa como "um asylo inviolavel"48 e podiam ter os seus aposentos invadidos ao bel prazer das autoridades. Parece absurdo, mas qualquer papel escrito em "língua estranha", ${ }^{49}$ qualquer símbolo "pagão" era, diante da paranoia e do clima conspiratório, um índice de culpa e um motivo para retaliações perversas. Como bem resume Reis, "o clima de medo incentivou a fúria dos vencedores" (REIS, 2003, p. 423) humilhados por terem sido desafiados por gente cuja "boçalidade e estupidez" fazia parte do inventário das diferenças. A maior parte da população baiana, conivente e paranoica, fez prosperar uma enxurrada de denúncias falsas, amplamente acolhidas pelas autoridades. E um sem fim de rumores.

43 "Relatório do chefe de polícia da Bahia, dirigido ao presidente da mesma província", 29 de janeiro de 1835. In: Ignace, 1909.

44 Étienne Ignace, 1907.

45 Reis, 2003.

46 In: Reis, 2003.

47 Justiça do preto Lobão de nação nagô. Anais do $A P E B a$, v. 53, p. 112.

48 Como podermos ler na Constituição de 1824.

49 Étienne Ignace afirma que algumas autoridades chegaram a afirmar que os papéis estavam escritos em hebraico (!). A esse respeito ver Ignace, 1907.

50 Ignace, 1907. 


\section{CONCLUSÃO}

As surras, as humilhações, os açoites e as execuções não foram as únicas consequências para aqueles africanos escravos e libertos envolvidos ou implicados na insurreição de janeiro. Uma extensa legislação antiafricana, que fazia parte de um rigoroso sistema de controle por parte dos senhores e do poder político, se desenvolveu no Brasil e, de modo bastante específico, na Província da Bahia. As "medidas preventivas" ${ }^{51}$ um verdadeiro código de opressão e vigilância, buscava tornar insuportável a vida daqueles que não deixavam a Província pela via da morte ou da deportação. E foi assim, afinal, que os africanos suspeitos foram punidos: para os libertos, deportação para a África. Para os escravos, expulsão ou venda para fora da Província, pois os senhores, temerosos de novas insurreições (que poderiam custar a morte ou prisão dos cativos que lhes garantiam rendimentos) se apressaram em vender os seus escravos para fora da Bahia.

Para os que insistiram em ficar na Bahia, o preço pago foi a arbitrariedade da polícia e a vigilância obsessiva por parte população baiana. O Edital de 21 de fevereiro de $1835,{ }^{52}$ assinado pelo chefe de polícia (e antiafricano convicto ${ }^{53}$ ), Francisco Gonçalves Martins, ${ }^{54}$ foi bastante direto: era necessário "pôr de uma vez termo aos continuados alarmes nocturnos que, depois da noite de 24 para 25 do passado, têm constantemente perturbado o socego das familias, bem como querendo providenciar a que um acontecimento semelhante ao daquela época não venha enluctar ainda uma vez os dias pacificos dos habitantes desta Cidade" e para isso era fundamental que o "desleixo indispensavel dos senhores de escravos" não permitisse que escravos transitassem "pelas ruas durante a noite". Assim, o Edital prescrevia que "todo escravo encontrado na rua sem escripto de seu senhor, declarando a que horas tem commissão de se demorar, bem como o lugar da moradia do mesmo senhor, será recolhido a cadêa e levara, na manhã seguinte, cincoenta açoutes, sendo além disto preciso, para ser solto, que seu senhor justifique nesta repartição, seu domínio, isenção do crime do dito escravo, e pague a carceragem competente". Sob os africanos libertos não pesava o mesmo rigor normativo, mas a arbitrariedade. Estes, "assim aprehendidos, terão um destino que se julgar conveniente".

${ }^{51}$ Ignace, 1907, p. 131.

${ }^{52} \mathrm{O}$ Edital lavrado pelo chefe de polícia da Bahia em 21 de fevereiro de 1835 foi publicado na íntegra como anexo da análise da insurreição de janeiro (intitulada "Os malês") do padre Étienne Ignace em 1909, na revista do IHGB, tomo LXXII (pp. 125-126).

${ }^{53}$ Reis, 2003.

${ }^{54}$ Curiosamente, Francisco Gonçalves Martins foi presidente da Província em duas ocasiões. 
Ao lado do aparato legislativo, uma crescente onda de vigilância generalizada tomou conta dos cidadãos baianos, sobretudo da elite comercial e rural. O chamado medo branco ganhou forma e o corpo negro passou a ser ainda mais significado pelo imperativo da hostilidade e da transgressão, devendo ser vigiado não apenas pelas instituições, mas também pela população O mesmo Edital, diz que "todo cidadão, guarda ou encarregado de Polícia, poderá e deverá fazer conduzir presos a este Juízo todos os escravos que forem encontrados em número de 4, sem que estejam empregados em algum serviço, principalmente nos contornos da cidade". A vida do africano liberto e escravo na cidade era regida por uma semântica da hostilidade, que regulava quantidade, movimento e lugar. Ao que parece, o número de 4 era relativamente arbitrário, na medida em que a legislação (o Código Criminal de 1830) previa que os crimes coletivos contra a "segurança interna do Imperio", e "publica tranquilidade" (conspiração, insurreição e sedição) tinham como base no mínimo 20 pessoas, salvo a rebelião, que demandava 20 mil envolvidos.

Esse medo generalizado, motivado pela paranoia de uma nova e iminente insurreição, se desdobra em duas frentes que foram, creio eu, tangenciadas neste trabalho: o discurso do controle do corpo negro, sobre o qual me detive mais de perto; e o rumor insurgente enquanto forma material do medo branco, que demanda uma análise mais cuidadosa na medida em que se trata de discursos relativamente autônomos, dotados de um espaço próprio de significância, mas que se atravessam de maneira a não ser possível pensar um sem o outro.

\section{REFERÊNCIAS}

ALTHUSSER, L. Pour Marx. Paris: Maspero, 1965.

ALTHUSSER, L. Sustentação da tese em Amiens. In: Graal, 1978. (pp. 129-167). . Posições, volume I. Rio de Janeiro:

AZEVEDO, C. M. de. Onda negra, medo branco: o negro no imaginário das elites no século XIX. Rio de Janeiro: Paz e Terra, 1987.

BARBOSA FILHO, F. R. Lingua, arquivo, acontecimento: trabalho de rua e revolta negra na Bahia oitocentista. Tese de doutorado apresentada ao Instituto de Estudos da Linguagem da Universidade Estadual de Campinas. Campinas, 2016.

BHABHA, H. O local da cultura. Belo Horizonte: Editora da UFMG, 1998.

BRITO, L. "Sem direitos, nem cidadania: condição legal e agência de mulheres e homens africanos na Bahia do século XIX”. In: História Unisinos, volume 14, n³ 3, 2010, pp. 334-338.

COURTINE, J-J. Análise do discurso politico: o discurso comunista endereçado aos cristãos. São Carlos: EDUFSCAR, 2009.

COSTA, E. V. da. A abolição. São Paulo: EDUNESP, $2010 a$.

COSTA, E. V. Da Monarquia à República: momentos decisivos. São Paulo: Editora UNESP, $2010 b$. 
ELIAS, N.; SCOTSON, J. Os estabelecidos e os outsiders: sociologia das relações de poder a partir de uma pequena comunidade. Tradução de Vera Ribeiro. Rio de Janeiro: Zahar, 2000.

FREGE, G. Lógica e filosofia da linguagem. Seleção, introdução, tradução e notas de Paulo Alcoforado. São Paulo: Editora da Universidade de São Paulo, 2009.

GORENDER, J. O escravismo colonial. São Paulo: Ática, 1978.

GUIMARÃES, E. Os sentidos de 'cidadão' no Império e na República no Brasil. In: GUIMARÃES, E.; ORLANDI, E. Língua e cidadania: o português no Brasil. Campinas: Pontes, 1996. (pp. 39-46).

HENRY, Paul. “Construções relativas e articulações discursivas”. In: Cadernos de Estudos Linguísticos, Campinas, $n^{\circ}$ 19, p.43-64, julho/dezembro, 1990.

HENRY, Paul. A ferramenta imperfeita: língua, sujeito e discurso. Campinas: Editora da Unicamp, 1992.

IGNACE, E. A revolta dos malês. In: Revista do Instituto Histórico e Geográfico do Brasil, ano XIV, $\mathrm{n}^{\circ} 33$, tomo LXXII, parte II, 1907, pp. 67-126.

IGNACE, E. Os malês. In: Revista do Instituto Histórico e Geográfico do Brasil, volume 72, $\mathrm{n}^{\circ} 2$, 1909, pp. 69-126.

LIMA, M. T. A construção discursiva do povo brasileiro: os discursos de $1^{\circ}$ de maio de Getúlio Vargas. Campinas: Editora da Unicamp, 1990.

NASCIMENTO, A. V. Dez freguesias da cidade de Salvador: aspectos sociais e urbanos do século XIX. Salvador: EDUFBA, 2007.

ORLANDI, E. "N/O limiar da cidade”. In: Revista Rua, Campinas, número especial, p. 7-19, julho, 1999.

ORLANDI, E. As formas do silêncio: no movimento dos sentidos. Campinas: Editora da UNICAMP, 2007a.

ORLANDI, E. Interpretação: autoria, leitura e efeitos do trabalho simbólico. Campinas: Pontes, $2007 b$.

PÊCHEUX, M. Delimitações, inversões, deslocamentos. In: Caderno de estudos linguísticos, ${ }^{\circ}$ 19, Campinas: Unicamp, 1990, pp. 7-24.

PÊCHEUX, M. Metáfora e interdiscurso. In: . Análise de Discurso, Michel Pêcheux: textos escolhidos por Eni Puccinelli Orlandi. Campinas: Pontes, 2011a. (pp. 151-162).

PÊCHEUX, M. Foi propaganda mesmo que você disse?. In: . Análise de Discurso, Michel Pêcheux: textos escolhidos por Eni Puccinelli Orlandi. Campinas: Pontes, 2011b. (pp. 73-92).

PÊCHEUX, M. Remontemos de Foucault a Spinoza. In: BARONAS, R. (Org.). Análise de discurso: apontamentos para uma história da noção-conceito de formação discursiva. São Carlos: Pedro \& João Editores, 2011c. (pp. 177-192).

PÊCHEUX, M. O discurso: estrutura ou acontecimento. Tradução de Eni Puccinelli Orlandi. Campinas: Pontes, 2006.

PÊCHEUX, M. Questões iniciais. In: CONEIN, B. et al. Materialidades discursivas. Campinas: Editora da UNICAMP, 2016a. (pp. 17-19). 
PÊCHEUX, M. O enunciado: encaixe, articulação e (des)ligação. In: CONEIN, B. et al. Materialidades discursivas. Campinas: Editora da UNICAMP, 2016b. (pp. 227-236).

REIS, J. J. Rebelião escrava no Brasil: a história do levante dos Malês. São Paulo: Brasiliense, 1986.

REIS, J. J. “A greve negra de 1857 na Bahia”. In: Revista USP, n 18. São Paulo: 1993, pp. 8-29.

REIS, J. J. Rebelião escrava no Brasil: a história do levante dos Malês em 1835. Edição revista e ampliada. São Paulo: Companhia das Letras, 2003.

TAVARES, L. H. D. História da Bahia. São Paulo: Editora UNESP; Salvador: EDUFBA, 2006.

VIANA, J. Liberdade na escravidão: uma abordagem semântica do conceito de liberdade em cartas de alforria. Tese de doutorado apresentada ao Instituto de Estudos da Linguagem da Universidade Estadual de Campinas. Campinas: UNICAMP, IEL, 2008.

ZOPPI-FONTANA, M. Objetos paradoxais e ideologia. In: Estudos da lingua(gem), n ${ }^{\circ}$, Vitória da Conquista: 2005b, pp. 41-59. 